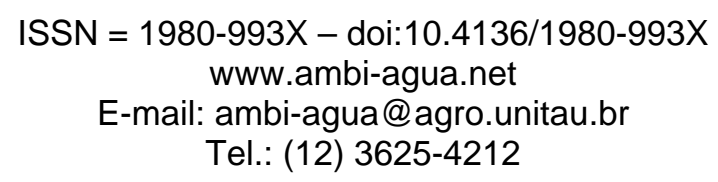

\title{
Land cover change and environmental quality assessment using GIS techniques - a case study in Brazilian Southeastern region for the period $1988-2003^{1}$ \\ (doi:10.4136/ambi-agua.135)
}

\author{
Alexandre Marco da Silva \\ UNESP - Campus de Sorocaba \\ E-mail: amsilva@sorocaba.unesp.br
}

\begin{abstract}
A close relation exists between the land cover situation and the environmental conditions of local wildlife species. This paper aimed to analyze the alterations of the land cover in two periods (1988 / 1995 and 1995 / 2003) regarding changes or persistence of the each land cover class and habitat assessment (establishment of categories of habitat quality) for a place in Brazilian Southeastern region. The study was carried out using digital land cover maps of the study area. Using a routine of GIS software, data were analyzed and the thematic maps generated. The data indicates that the region presented a dynamic land cover change, where almost a half of the study area presented changing in the land cover during the studied period. Major portion of the study area $(\sim 80 \%)$ was considered unsuitable for wildlife species establishment. It is urgent the necessity for a territorial reorganization in some regions aiming the construction of a biodiversity corridor to avoid a total isolation of the patches classified as primary habitat. The recovery of riparian forests along the rivers could accomplish it.
\end{abstract}

Keywords: land cover change; habitat quality assessment; biodiversity; landscape ecology.

\section{Alterações na cobertura do solo e avaliação da qualidade ambiental usando técnicas de SIG - um estudo de caso na região sudeste brasileira no período de 1988 a 2003}

\section{RESUMO}

Sabe-se que existe uma relação estreita entre a situação da cobertura do solo e as condições ambientais para as espécies silvestres. Este trabalho objetivou analisar as alterações da cobertura do solo em dois períodos (1988/1995 e 1995/2003) relacionando situações de alterações ou persistências de cada categoria de cobertura do solo e avaliação de qualidade de habitat (estabelecimento de categorias de habitat) para uma localidade na região sudeste brasileira. O estudo foi desenvolvido usando mapas digitais de cobertura do solo da área de estudo. Por meio de um módulo associado a uma plataforma de sistema de informação geográfica, os dados foram analisados e os mapas temáticos elaborados. Os dados indicam que a região apresentou uma alteração na cobertura do solo, onde quase a metade da área de estudo apresentou alteração na cobertura do solo durante o período de estudo. A maior parte da área de estudo ( $80 \%)$ foi considerada inapropriada para estabelecimento da vida silvestre. É urgente a necessidade de uma reorganização territorial em algumas regiões com o objetivo de se construir um corredor de biodiversidade para evitar o total isolamento the fragmentos classificadas como habitats de qualidade primária. A recuperação de florestas ciliares ao longo de cursos d’água poderia ser uma opção com êxito.

Palavras-chave: mudança na cobertura do solo; avaliação de qualidade de habitat; biodiversidade; ecologia de paisagem.

${ }^{1}$ - Financial support - FAPESP (grants: 04/13096-7 and 04/15796-6). 


\section{INTRODUCTION}

Current condition of the land cover normally constitutes the result of historical process of land use and land cover alteration since preterit periods (Lambin et al., 2003). Such process encompasses many of economic, social and environmental causes (Silva, 2004b). On the other hand, the situation of the land cover, especially in a remnant vegetation area (fragmented in major or minor degree), directly implicates on the habitat quality for wildlife species (Castro and Fernandez, 2004; Ferraz et al., 2007; Jorge and Garcia, 1997).

Aiming to establish guidelines for an adequate and sustainable management of the remnant vegetation and wildlife species, many studies employing GIS technology have been developed, where the maps are the key products (Becker et al., 2004; Korman, 2003). These products might indicate suitable and unsuitable areas for biological conservation and establishment of corridors for biological conservation (Gontier et al., 2006). They also constitute crucial database for planning, sometimes elaborated from preexistent land cover maps.

The Southeastern Brazilian region, in special the São Paulo State, constitutes an example of advanced degradation level (Brannstrom and Oliveira, 2000; Durigan et al., 2003). Many researchers located in São Paulo State have elaborated some procedures of investigation aiming to inspect the level of degradation, level of species extinction or danger and the identification of potential unities for biological conservation, among others (Metzger and Casatti, 2006).

On this context, and despite Sorocaba city (Figure 1) constituting an important ecological region due to proximity of two important biomes in Brazil (Mata Atlântica and Cerrado ecotone region), few studies concerning biodiversity were carried out for this region. Examples are Sussman and Rodrigues (2004), which investigated the use of a fluvial gallery located in a highway as corridor by mammal species; Calocci (1998) that studied the diversity of birds' species in an urban garden; and Smith and Barrella (2000) that studied the biodiversity of fish species in some marginal lagoons of Sorocaba River.

In this paper we analyzed the land cover change in two intervals (1988 / 1995 and 1995 / 2003) regarding the change or persistence of the each land cover class and habitat assessment (establishment of categories of habitat quality).

\section{METHODS}

\subsection{Environmental characterization of the study area}

The study area is Sorocaba (São Paulo State), a city located in the Southeastern of Brazil (Figure 1), with area of $456 \mathrm{~km}^{2}$ and 532,000 inhabitants (98\% of them living in urban settlements). It is considered as an important socio-economic center of the region, encompassing 1,078 industries (SEADE, 2006) and showing an advanced urban expansion. It is surrounded by others industrial cities, like Votorantim, Itu and Porto Feliz. 


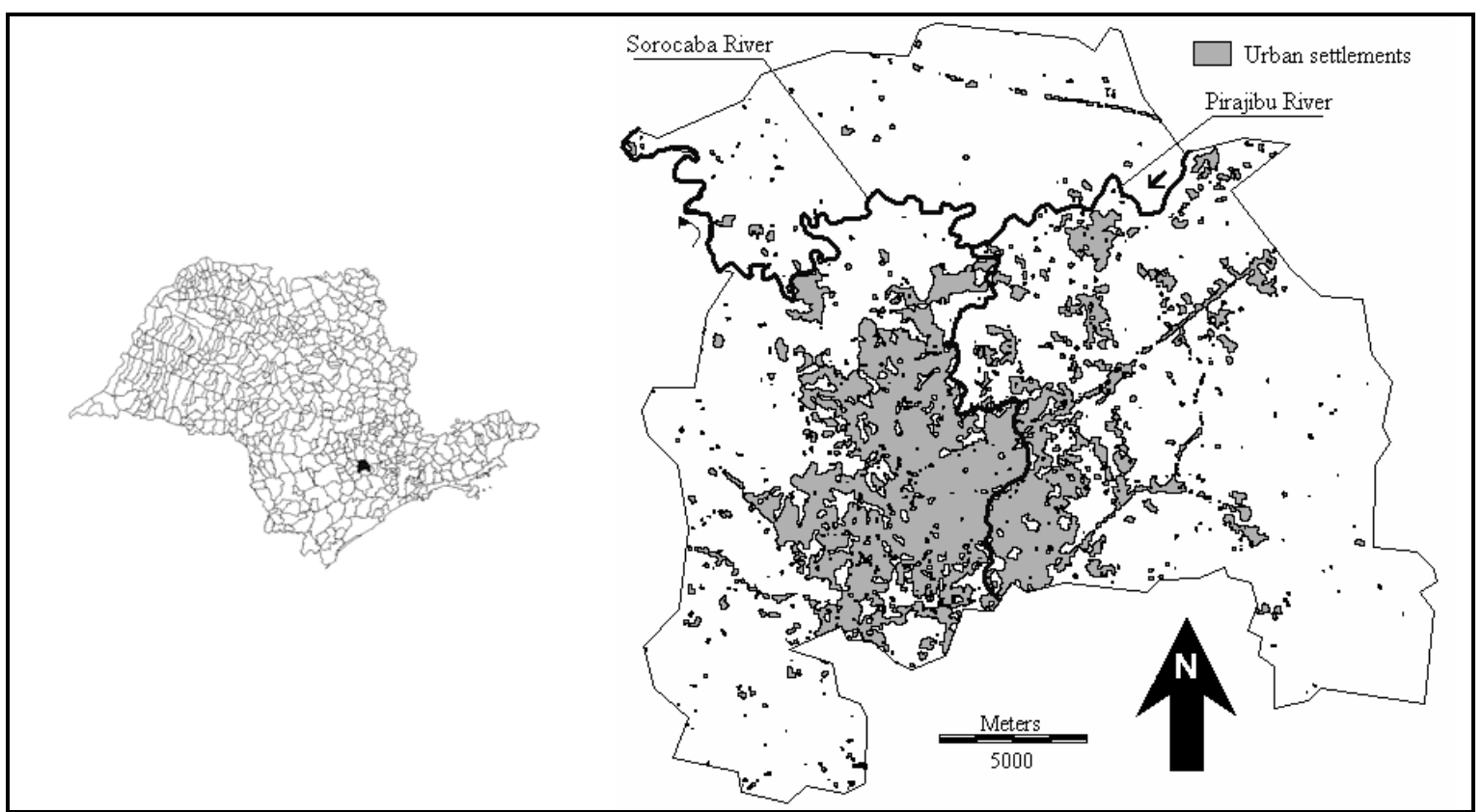

Figure 1. Left: Location of Sorocaba city in São Paulo State. Right: Sorocaba City, the main water courses and urban settlements.

The annual average temperature is $21.4^{\circ} \mathrm{C}$ and annual average rainfall height is $1,285 \mathrm{~mm}$. The topography is highly changeable. In the western portion, where the land is intensively used for agriculture, the relief is plane or smoothly waved. In the eastern portion, where the relief is waved to strongly waved, the remnant vegetation is more conserved. The topographic map of the city reveals that the elevation ranges from 500 to $1033 \mathrm{~m}$ above the sea level. There are two main soil classes: Yellow-red Alfisols and Red Oxisols, both dystrophic (Oliveira et al., 1999).

Sorocaba River is the main superficial water body of the region and it is highly impacted due to the launching of an untreated industrial and domestic wastewater; this condition generally cause a high impact of the riparian forest, especially in the urban perimeter of Sorocaba city (Smith and Barrella, 2000). In Sorocaba occurs the biome called "Mata Atlântica", but it is a transition area (ecotone) between the biomes "Mata Atlântica" and "Cerrado" (www.ibge.gov.br). It encompasses an area largely converted for agriculture, pasture (Sano et al., 2008) and urban expansion.

According to the newest land cover map of this city (Silva, 2005), the main land cover category is pasture, occupying $36.2 \%$ of the study area. The category urban settlement occupies $18.7 \%$, follow by the remnant vegetation and Reforestation categories (together), with $22.1 \%$.

\subsection{Procedures}

The land cover changes and habitat quality assessment for the study area were analyzed by using of a digital land cover map for three years: 1988, 1995 and 2003. These maps are presented in Silva (2005) already, including detailed methodology of classification. The land cover categories existing in these maps are: Pasture, Remnant Vegetation and Eucalyptus sp /Pinus sp areas (Reforestation), that were classified together as one single land cover class (NRV / Ref), Urban settlements, Bare soil, Water bodies, Cultures and Others. The class "Others" means all pixels not included in none land cover class. The class of principal interest for this study (NRV / Ref) is constituted by patches of natural remnant vegetation and some plantations of Pinus sp. and Eucalyptus sp. However, the area destined for Pinus sp. and Eucalyptus sp are small, and due to this the class "reforestation" was jointed with natural remnant vegetation (Silva, 2005). 
SILVA, A. M. Land cover change and environmental quality assessment using GIS techniques - a case study in Brazilian Southeastern region for the period 1988 - 2003. Ambi-Agua, Taubaté, v. 5, n. 2, p. 40-50, 2010. (doi:10.4136/ambi-agua.135)

Using the module of raster-based GIS software (Eastman, 2006), the gain and losses of each land cover class between the intervals 1988-1995 and 1995-2003 were evaluated.

Also using the same GIS module, it was assessed the quality of habitat for wildlife. The module is oriented to the pressing problem of accelerated land conversion and the very specific analytical needs of biodiversity conservation. For this part, the module requires that you insert two files corresponding to two land cover maps of different years. After, the module provides information, graphically or cartographically, contemplating five categories: primary habitat, secondary habitat, primary potential corridor, secondary potential corridor and unsuitable (Clark Labs, 2007). These categories are indicated below with a brief interpretation.

Primary Habitat. Areas of greatest conservation value. This is a habitat that presents all the necessary life needs in terms of size, access to forage, water, food, etc. In this case, the issue is specified by a minimum suitability (or habitat suitability map).

Secondary Habitat. Areas in which the designated habitat exists, but where one or more requirements are missing (such as minimum area or minimum suitability level) to serve as primary habitat. Secondary habitat areas provide forage and protection for dispersing animals as they are moving to new areas of primary habitat.

Primary Potential Corridor. Safety area indicating to animal species for traversing in any time, such as at night.

Secondary Potential Corridor. Areas that are known to be traversed by the species in question, but which constitute much riskier to the vegetal cover types.

Unsuitable. Areas that are not suited for habitat or corridors.

The module requires information regarding six parameters, whose numerical values were adopted according to information available in Valente (2001), who stated that the majority of species of mammals require a minimum area of 100 hectares to live, while for birds the minimum area is near of 10 ha and for insects the minimum area is 1 ha.

1) Minimum core area for primary habitat patches: 100 hectares;

2) Minimum edge buffer for primary habitat patches: 50 meters;

3) Minimum core area for secondary habitat patches: 50 hectares;

4) Minimal edge buffer for secondary habitat patches: 30 meters;

5) Minimum edge buffer for primary potential corridors: 30 meters;

6) Minimal edge buffer for secondary potential corridors: 10 meters.

About the corridors, the adopted values are similar to smaller value required for width of riparian vegetation for small streams, according to current Brazilian Forest Code. It is particularly difficult to establish accurate values for corridors because it is a very discussible concept by landscape ecologists and conservation biologists regarding the ideal strip width of the corridor in order to execute the functions for maintenance of biodiversity (Chetkiewicz et al., 2006).

\section{RESULTS AND DISCUSSION}

\subsection{Land cover change}

The Figure 2 shows the land cover change for the intervals 1988 - 1995 and 1995 - 2003 (net change values for such intervals). For 1988 - 1995, the bare soil category presented the major loss during this period, while the major gain was noted for the urban settlement category. For 1995 - 2003, the pasture category presented the largest loss, while the agriculture category presented the largest gain, followed by category urban settlement. 
SILVA, A. M. Land cover change and environmental quality assessment using GIS techniques - a case study in Brazilian Southeastern region for the period 1988 - 2003. Ambi-Agua, Taubaté, v. 5, n. 2, p. 40-50, 2010. (doi:10.4136/ambi-agua.135)
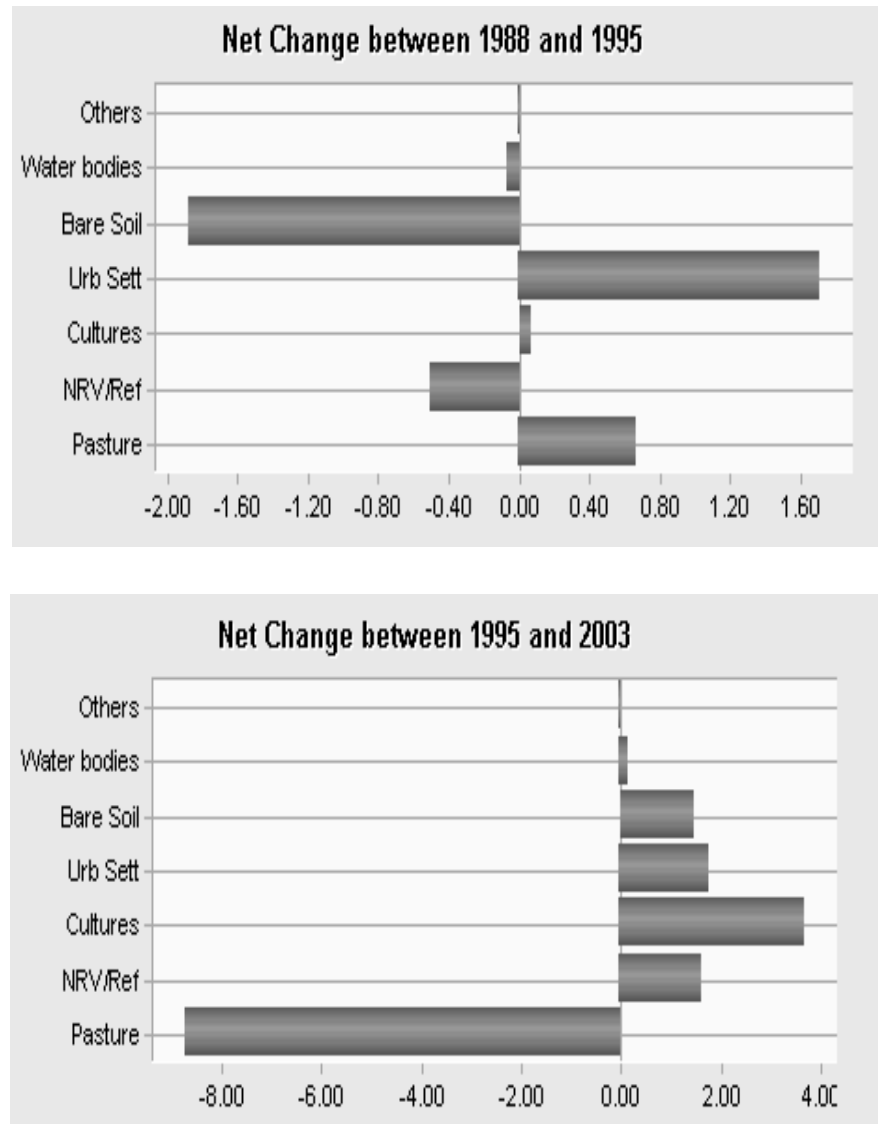

Figure 2. Net change between 1988 and 1995, and between 1995 and 2003 (values in \% of the total area).

Parallel to it, after the early 1980s, the population increased abundantly in Sorocaba (especially the urban population), explaining the increasing of the category "urban settlements". On the other hand, it is well known that the urban area can increase the effects of the land in rural areas through the ecological footprints (Lambin et al., 2003), that includes a large dependency of resources generated in rural and/or conservation areas, with the production of a large amount of wastes (atmospheric, solid and liquid), characterizing an expressive disturbed biogeochemical budget. For example, Martinelli et al. (2002) estimated that in Sorocaba there was the daily generation of $83,224 \mathrm{~m}^{3}$ of sewage and only $5 \%$ of this total was treated, classifying Sorocaba as one of the most polluting city of the São Paulo State. Smith and Barrella (2000) noticed an important relation between the diminution of fish species diversity in the marginal lagoons of Sorocaba River and the level of river pollution of that one. Silva and Leite (2004) estimated that yearly approximately 690,000 tons of $\mathrm{CO}_{2}$ are emitted by the vehicles in Sorocaba and daily 350 tons of domestic solid waste are produced (www.sorocaba.sp.gov.br).

The Figures 3 and 4 present the "persistence maps". These maps indicate spatial distribution of the land cover categories (patches with modifications and not modification). In $38.1 \%$ of the study area the land cover was the same during all studied period (or the equivalent to 2,636.6 ha of the class NRV / Ref did not changed). According to the Table 1, for the two investigated intervals, the percentage of area that the land cover has persisted was higher than the areas that experienced some kind of disturbance (or change). The values were similar between the two periods (comparing the data between the fields "persisted and persisted" and between "altered and altered").

In relation to the causes of land-use change, Lambin et al. (2003) mention five fundamental causes (each cause was subdivided into "fast" or "slow"): a) resource scarcity 
SILVA, A. M. Land cover change and environmental quality assessment using GIS techniques - a case study in Brazilian Southeastern region for the period 1988 - 2003. Ambi-Agua, Taubaté, v. 5, n. 2, p. 40-50, 2010. (doi:10.4136/ambi-agua.135)

causing pressure of production on natural resources; b) changing opportunities created by markets; c) outside policy intervention; d) loss of adaptive capability and increased vulnerability; e) changes in social organization, resource access and attitudes. The authors also mention that land-use change is driven by a combination of these causes. Considering these fundamental causes, it can be noticed that in Sorocaba the land cover transition is not a fixed pattern, nor deterministic.

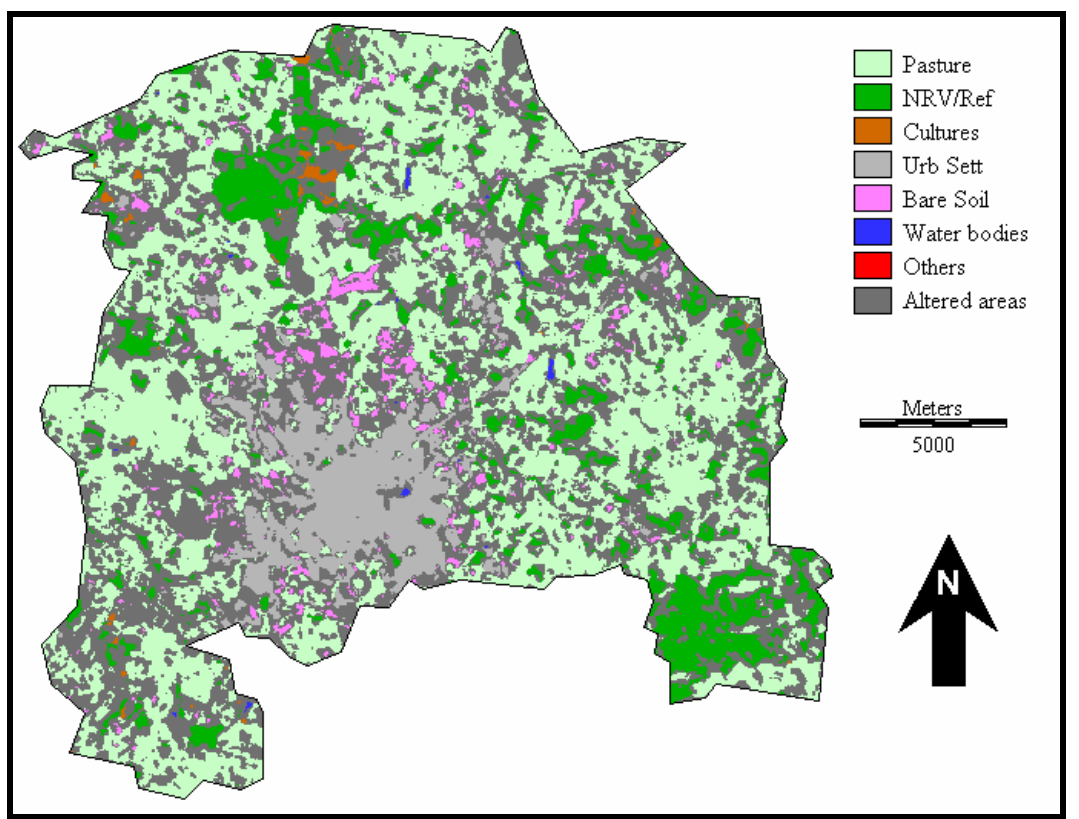

Figure 3. Persistence map for 1988 - 1995 period. All land cover classes indicate no land cover changing, exception to "altered areas", where changes occurred.

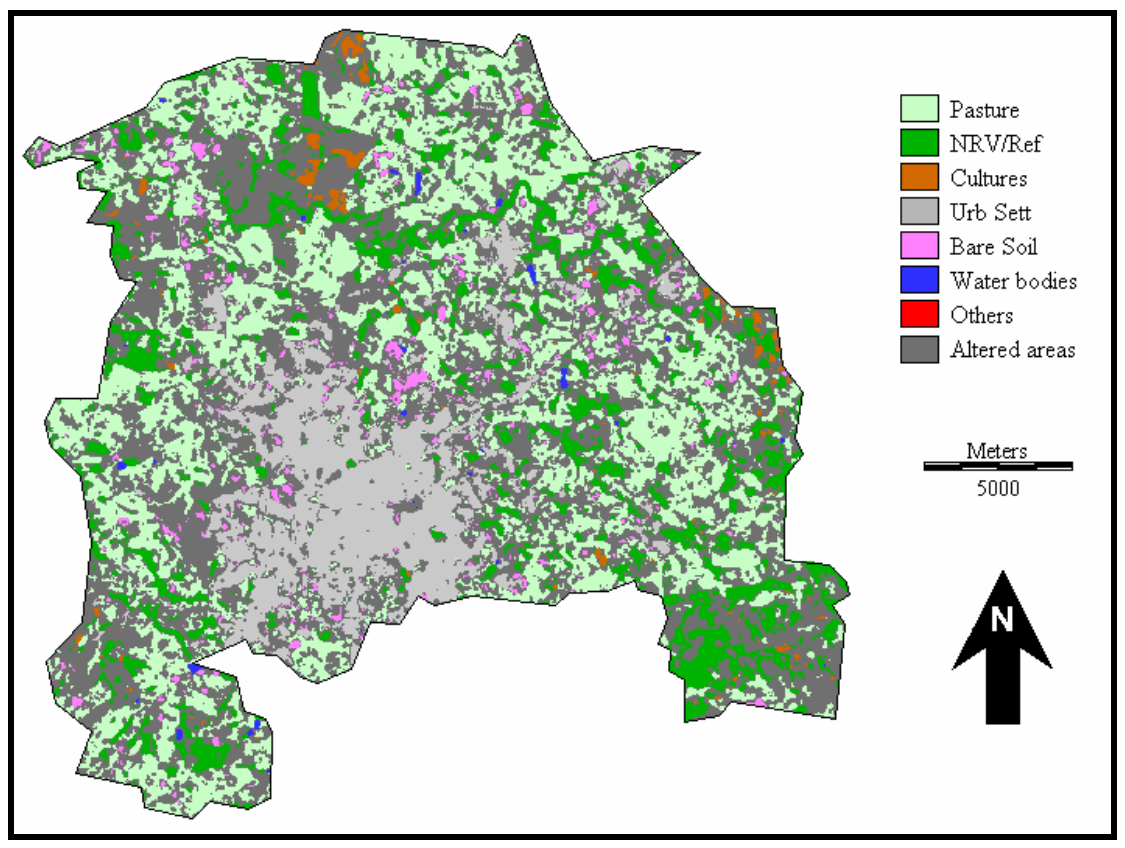

Figure 4. Persistence map for 1995 - 2003 period. All land cover classes indicate no land cover changing, exception to "altered areas", where changes occurred. 
SILVA, A. M. Land cover change and environmental quality assessment using GIS techniques - a case study in Brazilian Southeastern region for the period 1988 - 2003. Ambi-Agua, Taubaté, v. 5, n. 2, p. 40-50, 2010. (doi:10.4136/ambi-agua.135)

Table 1. Persistence values (\%) for 1988 - 1995 and 1995 - 2003.

\begin{tabular}{l|c|c}
\hline Category & $\mathbf{1 9 8 8 - \mathbf { 1 9 9 5 }}$ & $\mathbf{1 9 9 5 - \mathbf { 2 0 0 3 }}$ \\
\hline Persisted & 59.5 & 56.4 \\
Altered & 40.5 & 43.6 \\
\hline
\end{tabular}

\subsection{Habitat assessment}

The Table 2 and Figures 5, 6 and 7 present the database regarding habitat assessment of the study area for the years 1988, 1995 and 2003. Each habitat status category has presented similar percentage of occurrence among the studied years and the category "unsuitable" was largely predominant. The class "primary habitat" occupied approximately $9 \%$ of the study area for the three studied periods.

For the map presented in the Figure 7 (2003 - the most recent map) 16 isolated patches of "primary habitat" were computed, with area varying from 106 to 1,068 hectares (most of them with 100 to 200 hectares). Ferraz et al. (2007) found that the parameter area has a dominant effect over the persistence of birds; Castro and Fernandez (2004) verified similar effect for mammals. The level of isolation of others forest patches is also extremely important for the maintenance of the species. Once these patches are dispersed along the study area, a connection among such patches should be executed in order to facilitate the transition of the fauna.

The establishment of corridors using the riparian forest is an excellent option of patches connection (Hilty and Merenlender, 2004; Johnson et al., 1999). According to Naiman and Décamps (1997), riparian vegetation plays an important role for species like big mammals (e.g. carnivores, primates and edentates) and birds, once commonly more individuals and species are found in riparian habitats than in adjacent ones (Johnson et al., 1999). Silveira et al. (2009) verified that, for Sorocaba city, the $30 \mathrm{~m}$ width riparian corridors for all river network of the Sorocaba City encompass $20 \%$ of the total area due the high richness of rivers and streams that occur in the study site.

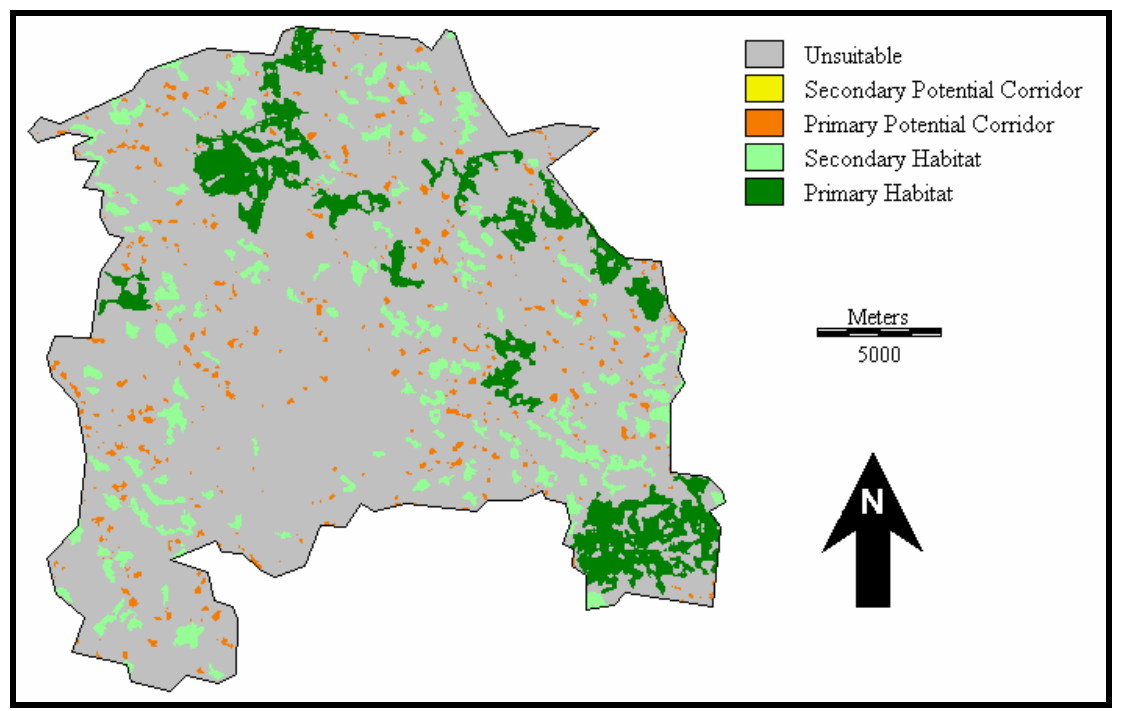

Figure 5. Habitat assessment map for 1988. 
SILVA, A. M. Land cover change and environmental quality assessment using GIS techniques - a case study in Brazilian Southeastern region for the period 1988 - 2003. Ambi-Agua, Taubaté, v. 5, n. 2, p. 40-50, 2010. (doi:10.4136/ambi-agua.135)

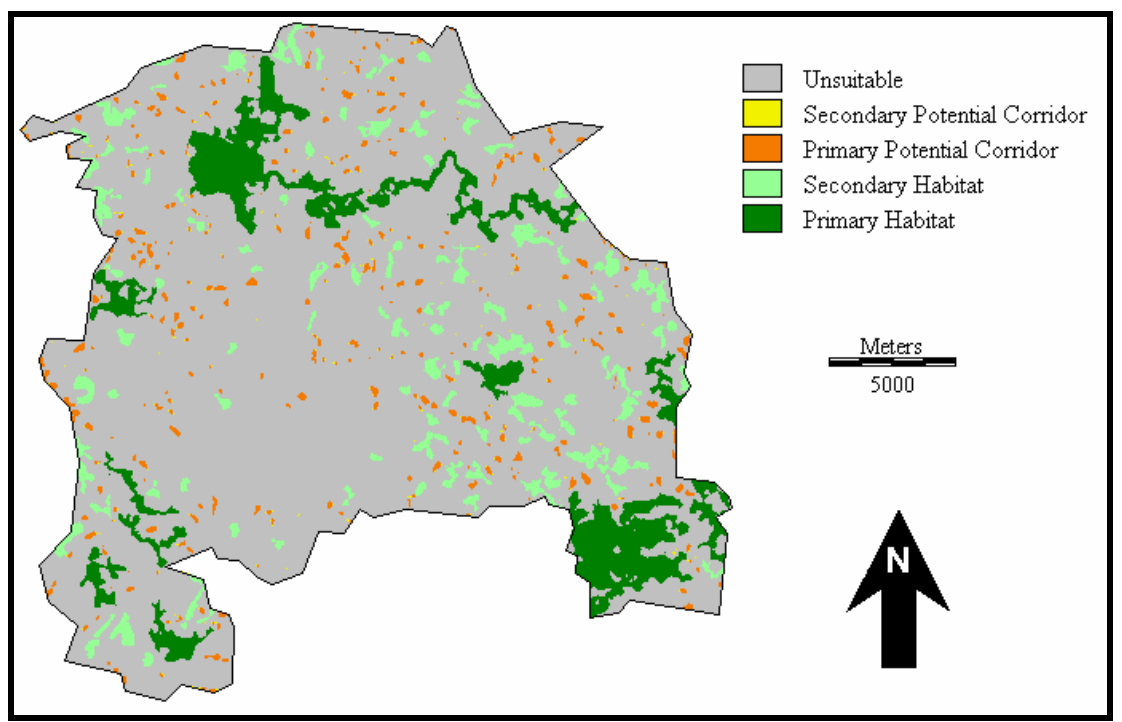

Figure 6. Habitat assessment map for 1995.

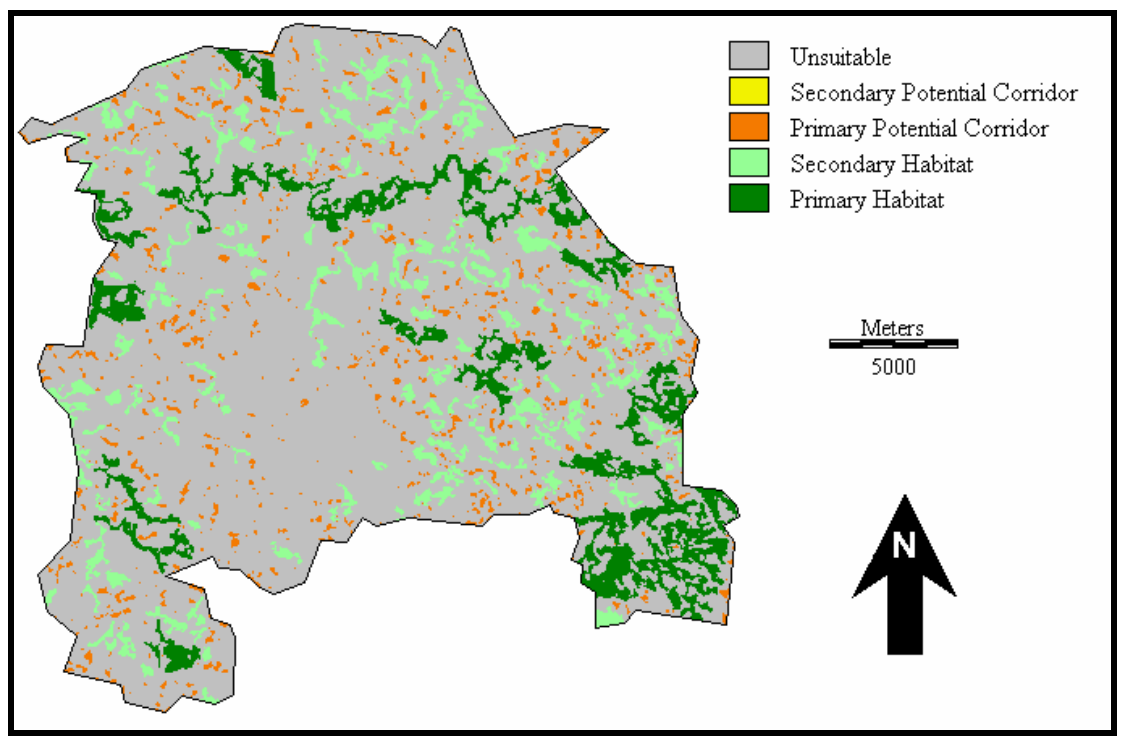

Figure 7. Habitat assessment map for 2003.

Table 2. Percentages of the five categories of habitat status for each period considered.

\begin{tabular}{l|c|c|c}
\hline Habitat status category & $\mathbf{1 9 8 8}$ & $\mathbf{1 9 9 5}$ & $\mathbf{2 0 0 3}$ \\
\hline Primary habitat & 9.4 & 9.5 & 9.3 \\
Secondary habitat & 7.6 & 6.1 & 8.5 \\
Primary potential corridor & 2.6 & 2.5 & 4.3 \\
Secondary potential corridor & 0.0 & 0.3 & 0.0 \\
Unsuitable & 80.5 & 81.6 & 77.9 \\
\hline
\end{tabular}

Overlapping the two maps (habitat assessment for 2003 and buffer strip map) was possible to verify that all primary habitat patches are connected if the riparian vegetation were preserved. Illustrating the necessity of connection, it was already verified that in this region the species of wild mammals use fluvial galleries to go from one patch to other (Sussman and Rodrigues, 2004). These authors have noticed that species as Mazama gouazoubira (deer), Hidrochaeris hidrochaeris (capybara), Myocastor coypus (coypu) were the main users of the gallery forest. 
It was perceived that the GIS technology favors the analysis and search for suitable habitats for biological conservation along the study area. Metzger and Casatti (2006) mention the selection of areas for biological conservation was traditionally based in opportunities, according to some criteria like level of conversion (natural environments $=$ intact forest landscapes), with a desirable idea of no human interference. This fact has resulted in a vicious distribution of the areas for conservation (remote areas, located normally in steep areas and/or with infertile soils).

The results for some ecosystems were poorly represented. Only recently the criteria for choosing areas for conservation were altered and currently biological parameters were incorporated in this process (Metzger and Casatti, 2006) and new approaches and technologies, as GIS, were implemented (Silva, 2004a). Hence an important research line is encouraging purposes whose aims are experimental diagnostic and restoration of degraded ecosystems. The results will help us rethink the current and future land cover situation in order to guarantee enough representative and suitable areas for wildlife conservation.

\section{CONCLUSIONS}

This study concludes that the Sorocaba city presented an intensive dynamic of land cover change during the investigated period. Only $9 \%$ of the study area meets all conditions for wildlife establishment in terms of resources for survivor and reproduction. The establishment of strategic areas for conservation and connecting patches, mainly through the establishment of corridors using the riparian forest, is an excellent option of patches connection is highly necessary and urgent.

\section{REFERENCES}

BECKER, F. G.; IRGANG, G. V.; HASENAK, H.; VILELLA, F. S.; VERANI, N. F. Land cover and conservation state of a region in the southern limit of the Atlantic forest (River Maquiné basin, RS, Brazil). Brazilian Journal of Biology, v. 64, p. 569 - 582, 2004.

BRANNSTROM, C.; OLIVEIRA, A. M. S. Human modification of stream valleys in the western plateau of São Paulo, Brazil: implications for environmental narratives and management. Land Degradation \& Development, v. 11, p. 535 - 548, 2000.

CALOCCI, P. C. Levantamento comparativo da comunidade de aves de três ambientes existentes no Parque da Biquinha, Sorocaba-SP. 1998. 10f. Monograph (Report) Pontifícia Universidade Católica de São Paulo, Sorocaba, 1998.

CASTRO, E. B. V.; FERNANDEZ, F. A. S. Determinants of differential extinction vulnerabilities of small mammals in Atlantic forest fragments in Brazil. Biological Conservation, v. 119, p. 73 - 80, 2004.

CHETKIEWICZ, C. B.; ST CLAIR, C. C.; BOYCE, M. S. Corridors for conservation: integrating pattern and process. Annual Review of Ecology, Evolution and Systematics, v. 37, p. 317 - 342, 2006.

CLARK LABS. The land change modeler for ecological sustainability. 2007. Available in: $<$ http://www.clarklabs.org/applications/upload/Land-Change-Modeler-IDRISI-FocusPaper.pdf $>$. Access: Aug. 2010. 
DURIGAN, G.; SIQUEIRA, M. F.; FRANCO, G. A. D. C.; BRIDGEWATER, S.; RATTER, J. A. The vegetation of priority areas for Cerrado conservation in São Paulo State, Brazil. Edinburgh Journal of Botany, v. 60, p. 217 - 241, 2003.

EASTMAN, R. Idrisi for Windows: andes version: tutorial. Worcester: Clark University, 2006. 284 p.

FERRAZ, G.; NICHOLS, J. D.; HINES, J. E.; STOUFFER, P. C.; BIERREGAARD, O. R.; LOVEJOY, T. E. A large-scale deforestation experiment: effects of patch area and isolation on Amazon birds. Science, v. 315, p. 238 - 241, 2007.

FUNDAÇÃO SISTEMA ESTADUAL DE ANÁLISE DE DADOS - SEADE. População e estatísticas vitais. 2006. Available in: <http://www.seade.sp.gov.br>. Access: Aug. 2010.

GONTIER, M.; BALFORS, B.; MÖRTBERG, U. Biodiversity in environmental assessment current practice and tools for prediction. Environmental Impact Assessment Review, v. 26, p. $268-286,2006$.

HILTY, J. A.; MERENLENDER, A. Use of riparian corridors and vineyards by mammalian predators in Northern California. Conservation Biology, v. 18, p. 126 - 135, 2004.

JOHNSON, M. A.; SARAIVA, P. M.; COELHO, D. The role of gallery forests in the distribution of Cerrado mammals. Brazilian Journal of Biology, v. 59, p. 421 - 427, 1999.

JORGE, L. A. B.; GARCIA, G. J. A study of habitat fragmentation in Southeastern Brazil using remote sensing and geographic information system. Forest Ecology and Management, v. 98, p. 35 - 47, 1997.

KORMAN, V. Proposta de interligação das glebas do Parque Estadual de Vassunga. 2003. 141f. Dissertation (Master's Degree in Ecology of Agroecosystems) - Escola Superior de Agricultura "Luiz de Queiroz", Universidade de São Paulo, Piracicaba, 2003.

LAMBIN, E. F.; GEIST, H. J.; LEPERS, E. Dynamics of Land-use and Land-cover change in Tropical regions. Annual Review of Environmental Resources, v. 28, p. 205 - 241, 2003.

MARTINELLI, L. A.; SILVA, A. M.; CAMARGO, P. B.; MORETTI, L. R.; TOMAZELLI, A. C.; SILVA, D. M. L. et al. Levantamento das cargas orgânicas lançadas nos rios do estado de São Paulo. Biotaneotropica, v. 2, p. 18, 2002.

METZGER, J. P. W.; CASATTI, L. Do diagnóstico à conservação da biodiversidade: o estado da arte do programa BIOTA/FAPESP. Biotaneotropica, v. 6, p. 1-23, 2006.

NAIMAN, R. J.; DÉCAMPS, H. The ecology of interfaces: riparian zones. Annual Review of Ecology and Systematics, v. 28, p. 621 - 658, 1997.

OLIVEIRA, J. B. DE; CAMARGO, M. N.; ROSSI, M.; CALDERANO FILHO, B. Mapa pedológico do Estado de São Paulo. Legenda Expandida. Campinas: Instituto Agronômico: EMBRAPA - Solos, 1999. 64 p.

SANO, E. E.; ROSA, R.; BRITO, J. L. S.; FERREIRA, L. G. Mapeamento semidetalhado do uso da terra do Bioma Cerrado. Pesquisa Agropecuária Brasileira, v. 43, n. 1, p. 153 156, 2008. 
SILVA, A. M. Análise da cobertura do solo da área de entorno de três unidades de conservação localizadas no estado de São Paulo. Holos - Environment, v. 4, p. 130 144, 2004 a.

SILVA, A. M. Ecologia de paisagem: fundamentos e aplicações. Rio de Janeiro: Papel Virtual, 2004b. 157 p.

SILVA, A. M. Cobertura do solo do município de Sorocaba-SP e implicações na fragmentação dos remanescentes florestais. Revista de Estudos Ambientais, v. 7, p. 38 - 46, 2005.

SILVA, A. M.; LEITE, A. M..Estimativa da emissão anual de $\mathrm{CO}_{2}$ de combustíveis para os municípios do Estado de São Paulo. Revista de Estudos Ambientais, v. 6, n. 2/3, p. 18-32, 2004.

SILVEIRA, F. M.; SILVA, A. M.; IKEMATSU, P.; PAULA, F. P.; NOGUEIRA, D. P.; ALVES, S. H. et al. Variation of the occupied area by riparian zone according to considered width Caminhos de Geografia, v. 10, n. 30, p. 111 - 119, 2009.

SMITH, W. S.; BARRELLA, W. The ichthyofauna of the marginal lagoons of the Sorocaba River, SP, Brazil: composition, abundance and effect of the anthropogenic actions. Brazilian Journal of Biology, v. 60, p. 627 - 632, 2000.

SUSSMAN, R. A. C.; RODRIGUES, U. J. C. 2004. Uso da galeria fluvial localizada no km $\mathbf{7 7 , 5}$ da rodovia Castello Branco como corredor de mastofauna. 2004. $10 \mathrm{f}$. Monograph (Report) - Pontifícia Universidade Católica de São Paulo, Sorocaba, 2004.

VALENTE, R. DE O. A. Análise da estrutura da paisagem na bacia do Rio Corumbataí, SP. 2001. 144f. Dissertation (Master's Degree in Forest Resources) - Escola Superior de Agricultura “Luiz de Queiroz”, Universidade de São Paulo, Piracicaba, 2001. 